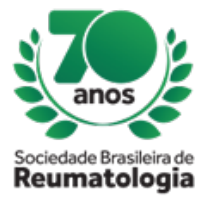

\title{
PULMONARY CYSTS: VERY COMMON FINDING ON COMPUTED TOMOGRAPHY OF THE CHEST OF ASYMPTOMATIC PATIENTS WITH PRIMARY SJOGREN'S SYNDROME
}

\author{
ALISSON ALIEL VIGANO PUGLIESI (UNIVERSIDADE ESTADUAL DE CAMPINAS, Campinas, SP, Brasil), \\ PAMELLA PAULA BELLINI (UNIVERSIDADE ESTADUAL DE CAMPINAS, Campinas, SP, Brasil), RACHEL \\ ZERBINI MARIANO (UNIVERSIDADE ESTADUAL DE CAMPINAS, CAMPINAS, SP, Brasil), MANOEL BARROS \\ BERTOLO (UNIVERSIDADE ESTADUAL DE CAMPINAS, Campinas, SP, Brasil), Zoraida Sachetto \\ (UNIVERSIDADE ESTADUAL DE CAMPINAS, Campinas, SP, Brasil)
}

\section{BACKGROUND}

The presence of pulmonary cysts is a relatively unusual radiological finding, but frequently described in patients with primary Sjögren's syndrome (pSS). Its true meaning, however, remains unclear, and may be associated with other forms of interstitial lung disease, lymphoma, or even a benign finding. Previous data on the subject are retrospective and also involve secondary forms of the disease, in addition to evaluations of CT scans of the chest. Our main objective is to evaluate the prevalence of pulmonary cysts in asymptomatic respiratory patients with pSS, as well as possible clinical-laboratory association factors.

\section{MATERIALS AND METHODS}

From September 2017 to April 2019, patients with pSS and without any form of respiratory symptomatology were selected for high-resolution computed tomography (HRCT). Patients older than 18 years and classified as having Sjögren's syndrome (SS) were included according to the American-European Consensus of 2002 ( $68.5 \%$ of the individuals met the 2016 ACR criteria). Only patients with the primary form of the disease were recruited. A single, experienced radiologist evaluated the images. A cyst was defined by the presence of a clearly demarcated airspace surrounded by thin $(<2 \mathrm{~mm})$ walls. Numbers, size, and lung distribution of cysts were analyzed. Epidemiological, clinical, and laboratory data were extracted from medical records. Data from pSS patients with and without pulmonary cysts were compared, and Fisher's exact test was used to evaluate statistical association.

\section{RESULTS}

Thirty-five pSS patients (median age $\pm 52.3 ; 100 \%$ female) and respiratory asymptomatic patients underwent $\mathrm{CT}$ of the thorax. Of these, 11 (31\%) presented evidence of pulmonary cysts, mainly in the lower lobe $(75 \%)$ and with a size varying from 0.3 to $6.6 \mathrm{~cm}$. No extraglandular (renal, neurological, cutaneous, articular or hematologic), autoantibody (anti-Ro, anti-La, RF, ANA) or laboratorial manifestations (complement dosage, cryoglobulins, protein electrophoresis) were statistically associated with pulmonary cysts found on chest CT.

\section{CONCLUSION}

The high prevalence of pulmonary cysts in asymptomatic respiratory patients with pSS reinforces their probable benign nature, as well as the important association of this unusual pulmonary finding with this form of connective tissue disease. No clinical-laboratory element related to pSS was associated with this pulmonary manifestation. Prospective evaluation of this and other studies is necessary for a better understanding of the evolutionary nature of pulmonary cysts. 